\section{Clinical Legal Education-A Robust Instrument for Attainment of Justice: An Indian Perspective}

\author{
Ravindra Kumar Singh'
}

Asian Journal of Legal Education 9(I) 7-22, 2022

(C) 202I The West Bengal National University of Juridical Sciences Reprints and permissions: in.sagepub.com/journals-permissions-india

DOI: I0.II77/097|72I82II 030784 journals.sagepub.com/home/ale

(SAGE

\begin{abstract}
Legal education is to serve the purpose of creating well-versed and proficient professionals who can render the best legal service to the people and help them get justice. Moreover, it is also to produce lawabiding and well-informed citizens who can carry out their duties in their professional life (irrespective of the nature of profession) for maintaining the rule of law. Along with a very strong foundation of substantive law, law students must also be oriented to the application of law during their undergraduate programme. This goal is to be realized through clinical legal education (CLE), which was introduced with an aim of combining the theory with practice. It also helps inculcate a sense of social justice in law students, as they closely see the application of law in a real life situation; they realize how law benefits people; they get closely connected to the society; they learn professional ethics; they develop problem solving approach; they get immeasurable satisfaction and confidence in the power of law; and more particularly, they comprehend that law is the real robust instrument to ensure and secure inclusive justice in the society. CLE, thus, makes the legal education all-inclusive and wholesome by making law students the agents of social change and champions of justice. This research article argues that CLE is indispensable for the attainment of inclusive justice. It also gauges the state of CLE in India from this perspective. Lastly, the article offers a few convincing suggestions which need to be incorporated in the legal education framework of India in order to ensure the higher goal of attainment of inclusive justice in India.
\end{abstract}

\title{
Introduction
}

Legal education, in particular, produces proficient professionals, in addition to serving the society by creating law-abiding and well-informed citizens who are needed in every profession for maintaining the

Disclaimer: This research article is the revised and upgraded version of the paper which the author submitted to and presented at the 17th ASLI (Asian Law Institute) Conference held (online) and co-organized by the National Law University, Delhi and the Asian Law Institute from 7 November 2020 to 9 November 2020.As per the policy of ASLI Conference, neither the soft copies nor hard copies of individual papers will constitute publication; and the individual presenters retain copyright of their papers and are free to submit them for publication elsewhere.

' Associate Professor of Law, Former Dean (Academic Affairs), Gujarat National Law University \& Former ICCR Rotating Chair (Visiting Professor of Indian Studies), Leibniz University Hannover, Germany.

\section{Corresponding author:}

Ravindra Kumar Singh, Associate Professor of Law, Former Dean (Academic Affairs), Gujarat National Law University, Koba, Gandhinagar 382426, Gujarat, India.

E-mails: rsingh@gnlu.ac.in; ravindrasinghshoorwar@yahoo.co.in 
rule of law in society. As a general rule, it is the quality of education which lays the true foundation and ensures success in the professional life. As a whole, for providing quality legal education, the law universities and colleges must have: quality faculty members, robust curriculum addressing the domestic and international issues and challenges, continuous pedagogic improvements, good infrastructure facilities, adequate funding, so on and so forth. Besides adequately incorporating the domestic laws (on which there can be no compromise), the curriculum should also ideally integrate the following: (a) the areas of law which are of transnational nature, (b) legal contours of international issues and (c) transnational dimensions of core and substantive areas of law. ${ }^{2}$

A very strong foundation of substantive law is extremely important for the doctrinal and theoretical understanding of the law. In conjunction with the substantive law, legal analysis, legal synthesis and legal doctrines - law students must also be appropriately oriented to the application of law during their undergraduate law programme. This object is primarily to be achieved by dint of clinical legal education (CLE) and the internships which the students are to undergo during their law programme. The purpose of this article is to outline the development of CLE in India, and to discuss how CLE can, as a part of the legal education framework, make certain the attainment of inclusive justice in India.

\section{Clinical Legal Education and Its Importance}

This part of the article discusses the importance of CLE for the attainment of justice. The law curriculum should be in sync with the social transformation happening around, and law students should get more connected to the society and be able to see the application of the law while pursuing their law programme. The need for country-wide reformation in legal education is felt not just in India. Such a need is felt elsewhere also. In their scholarly book, Reinventing Legal Education, Alberto Alemanno and Lamin Khadar write that 'CLE in Europe emerges out of and must be construed in the light of a broad reflective turn in European legal education'. ${ }^{3}$ Further, the following apt observation of these scholars states the imperative necessity of transforming legal education: ${ }^{4}$

The urgent need to reform legal education in light of the Europeanization and internationalization of national legal systems, the globalization of legal practice, and the equal demand for civic engagement in view of increasingly powerful supranational institutions and international actors appear among a number of catalysts and incentives for the emergence of university law clinics in Europe. Through the European clinical movement, spurred on by this restructuring of the European legal field, European legal teaching-historically formalistic, doctrinal,

\footnotetext{
${ }^{2}$ See William Twining, Globalisation And Legal Scholarship 29-31(2011). In this book, William Twining has discerned the following noticeable trends of the effect of globalization on legal fields: (a) 'First, greater emphasis is being placed on established transnational fields' (such as, public international law, environmental law, international trade and finance, etc.) and emergence of new transnational fields (such as, internet law, international taxation, etc.). (b) 'Increased recognition of the legal dimensions of issues and phenomena that are genuinely global' (for example, climate change, other environmental issues, terrorism, pandemics, etc.). (c) 'Third ... there is a growing emphasis on the transnational dimensions of subjects previously perceived as domestic' (for instance, contract law, family law, etc.). (d) 'Fourth, increasing attention is being paid to diffusion of law generally, and specifically of religious and customary practices through migration'. (e) 'Finally, today no scholar, or even student, of law can focus solely on the domestic law of a single jurisdiction'.

${ }^{3}$ Alberto Alemanno \& Lamin Khadar, Reinventing Legal Education: How Clinical Education is Reforming the Teaching and Practice of LaW in Europe 336 (2018). This book gathers scholarly and systematic reflections on the fascinating and rapid developments taking place in European legal teaching and practice, as viewed through the lens of CLE. It highlights how CLE is reinventing legal education in Europe.

${ }^{4}$ Id. at $3-4$.
} 
hierarchical, and passive (lecture and textbook-based) - is coming under increasing pressure to reimagine itself as pragmatic, policy-aware, and action-oriented. In line with its genesis and development in the United States, European CLE emerges today in response to the limits of traditional legal education to teach students in the complex ways of thinking and acting increasingly required of lawyers if they are to fulfil their vital roles in society.

In the United States, CLE experienced a fast progression during the American civil rights and public interest law movements in the 1960s-1970s; and all through this period, the Ford Foundation provided extensive funding towards the establishment of law clinics at universities. ${ }^{5}$ Corresponding to the CLE experience in the United States, the clinical movement evolved and law clinics were established in countries such as India, the United Kingdom, Australia, Canada, Botswana, Tanzania, Chile, Peru and Argentina during the 1960s-1970s (also in the 1980s); therefore, this period can rightly be characterized as the period of global clinical movement. ${ }^{6}$ The object behind introducing CLE was to blend the theory with the practical aspects of law. The Report of the Committee on the Future of the In-House Clinic (published by the Association of American Law Schools) identified the following nine goals of clinical education: ${ }^{7}$

1. 'Developing modes of planning and analysis for dealing with unstructured situations': The aim of this goal is to teach students as to how to be 'reflective practitioners'.

2. 'Providing professional skills instruction': This self-explanatory goal, which motivates students to learn and apply professional skills, is best accomplished by simulations.

3. 'Teaching means of learning from experience': This aims at providing ways by which students can learn from experience.

4. 'Instructing students in professional responsibility': It aims at developing professional responsibility, ethical understanding, and professional self-awareness among students.

5. 'Exposing students to the demands and methods of acting in role': This involves the interpersonal side of advocacy, and teaches students the lawyer-client relationship from diverse standpoints.

6. 'Providing opportunities for collaborative learning': The importance of this goal lies in the fact that training and performance in legal practice happen in a shared environment.

7. 'Imparting the obligation for service to indigent clients, information about how to engage in such representation, and knowledge concerning the impact of the legal system on poor people': The object of this goal is to provide the experience of representing deprived and needy clients and the chance for reflection on such representations.

8. 'Providing the opportunity for examining the impact of doctrine in real life and providing a laboratory in which students and faculty study particular areas of the law': By investigating and realizing the effect of doctrines on individual lives, students develop their understanding of those doctrines, which could lead to refined student involvement in law reforms.

9. 'Critiquing the capacities and limitations of lawyers and the legal system': The object behind this goal is to offer an opportunity for scrutinizing the working of legal institutions and how their efficiency can be enhanced.

${ }^{5} I d$. at 5 .

${ }^{6}$ Id. See also Richard J. Wilson, Training for Justice: The Global Reach of Clinical Legal Education, 22 Penn St. Int'L L. Rev. 421 (2004). https://elibrary.law.psu.edu/cgi/viewcontent.cgi?article=1595\&context=psilr.

${ }^{7}$ Robert Dinerstein, Report of the Committee on the Future of the In-House Clinic August 1990, Revised October 1991, 42 J. LEGAL Educ. 508, 511-517 (1992). https://www.jstor.org/stable/pdf/42898311.pdf. 
Since CLE provides an opportunity to law students to see the application of law in a real life situation, it offers the following key advantages: ${ }^{8}$

1. It helps develop a sense of social justice among the students.

2. It makes them aware of the aid, assistance and support — which the law provides to the people.

3. It helps them realize the real might and working of the law at the ground level. They learn by gaining practical experience, that is, learning by doing.

4. It provides them with an opportunity to assist the needy and the underprivileged.

5. It helps them get closely connected to the society.

6. It helps them learn professional skills, attitudes, values and ethics - which must be possessed by an ideal legal professional.

7. It helps them understand the practical approach to the application of law.

8. It helps them understand the significance and the need for alternative dispute resolution mechanisms for the resolution of disputes.

9. It enhances professional and cognitive developments.

10. In the real life situations (legal aid clinics, and so on), law students are more likely to think and act like a legal professional.

11. It helps them develop problem-solving abilities and approach.

12. It develops them into more rational and responsible citizens who could take part in the reformation of the legal system of the country.

13. It helps develop a sense of social, moral and constitutional responsibility among students.

14. It motivates students to get into legal entrepreneurship.

15. It helps them feel incalculable contentment when they see that law is the real robust instrument to ensure and secure inclusive justice in the society.

The purpose of CLE is, thus, not just equipping law students with certain lawyering skills and attitudes. It serves a much larger purpose. The afore-stated benefits of CLE sufficiently establish that it (CLE) makes the legal education all-inclusive and far-reaching by making law students the agents of social change and defenders of justice, while they pursue their undergraduate programme in universities and colleges. Professor N. R. Madhava Menon, the father of modern legal education in India, highlights the broader objectives of CLE in the following words: ${ }^{9}$

Clinical Legal Education has wider goals of enabling law students to understand and assimilate responsibilities as a member of a public service in the administration of the law, in the reform of the law, in the equitable distribution of the legal services in society, in the protection of individual rights and public interests and in upholding the basic elements of 'professionalism.'

\footnotetext{
${ }^{8}$ See Ravindra Kumar Singh, Role of National Law Universities in Transforming Legal Education in Modern India-A Critical Appraisal, in Legal Education In India: Essays In Honour Of Professor Ranbir Singh 376-429 (Lokendra Malik \& Manish Arora eds., 2014). Besides stating the importance and goals of CLE, this long essay (written by the author of this article) outlines the state of legal education in India and the changes brought forth by National Law Universities (NLUs), and also puts forth some very crucial suggestions for raising the overall standards of legal education and how the NLUs could bring about the next generation of reforms in legal education.

${ }^{9}$ N. R. Madhava Menon, Clinical Legal Education 1 (1998).
} 


\section{The State of Clinical Legal Education in India}

This part of the article presents the current state of affairs of CLE in India. The Bar Council of India (BCI), established under the Advocates Act, 1961, is the regulatory body for legal education and legal profession whose function, inter alia, is 'to promote legal education and to lay down standards of such education in consultation with the Universities in India imparting such education and the State Bar Councils'. ${ }^{10}$

With the advent of the NLUs, the standards of legal education have definitely gone high; yet overall, the existing status of CLE in India has not reached the desired level. This fact is little disappointing for both legal education and legal profession. Experience says that students, in general, do not attach the due importance to these clinical courses. There could be diverse reasons for the same. For instance, these courses/papers are not offered and handled in the way they should actually be taught/conducted. It has to be understood unmistakeably that these courses deserve a different approach than the other regular courses on substantive law. It is a strong belief of the author that the treatment meted out to the clinical courses is the reason why these courses have not become so popular and beneficial. These courses require faculty members specially trained in CLE, better infrastructural facilities, and so on. More so, apart from the NLUs and some other reputed universities and institutions, there are hundreds of law colleges in the country, where owing to diverse factors (inadequate number of faculty members, scanty funding, insufficient infrastructure, etc.), the quality of legal education (including CLE) is not up to the mark.

The development of CLE in India can broadly be divided into three phases. The legal aid clinic movement, started in the 1960s, represents the first phase. ${ }^{11}$ The 1990s mark the second phase. During this phase of development, in the year 1997, the BCI mandated the incorporation of four practical papers in the law curriculum; and the third phase begins with the integration of clinical courses (with brief specifics and guidelines) in the BCI's Legal Education Rules 2008. Thus, it was a long journey from 'having no clinical courses' to formally 'having mandated clinical courses' in the law programme. However, merely having clinical courses in the curriculum, and somehow concluding them-is not sufficient. It has indeed been long overdue that the law schools in India should genuinely accomplish the true essence of such courses. Now, there is a need to initiate the next generation reforms in CLE by ensuring that the real objective behind the introduction of clinical courses is attained, that is, implanting, inculcating and transmitting the spirit of CLE. This could be done by exploring, innovating and implementing all possible avenues and activities in the clinical courses.

\section{Phase I}

The involvement of students in the legal aid clinic was to improve legal education, by making it 'socially relevant' and 'professionally valuable', for the legal aid clinic was considered a good instrument to teach professional responsibility and a sense of public service, along with developing necessary skills and

\footnotetext{
${ }^{10}$ Section 7(1)(h) of the Advocates Act, 1961.

${ }^{11}$ At Delhi Law Faculty, a legal services clinic was voluntarily set up by some faculty members and students to render legal services to inmates of prisons and custodial institutions. See Menon, supra note 9 at 18 . Some other colleges where legal aid clinics were functioning on optional basis were Renukacharya Law College, Bangalore and Government Law College, Calicut. See also Report of the Expert Committee on Legal Aid titled, Processual Justice to the People, 157 (Government of India 1973 ). This Expert Committee was appointed by the Government of India under the Chairmanship of Justice V. R. Krishna Iyer. The Committee recommended that 'law colleges and law departments should be encouraged to start student law clinics engaged in a variety of programmes ranging from community education projects to actual representation of cases in court on behalf of indigents'.
} 
perspectives. ${ }^{12}$ This marked the beginning of CLE in India through voluntarily established legal aid clinics, as these clinics provided the scope for necessary skill development which was otherwise not possible in the traditional law curriculum. Gradually, many universities and colleges started legal aid clinics either as a part of curriculum or as an extra-curricular activity. In the year 1977, the expert committee appointed by the Government of India, with Justices V.R. Krishna Iyer and P.N. Bhagwati as its members, submitted the Report on National Juridicare: Equal Justice, Social Justice, which recommended for the establishment of national level council for legal services clinics. According to this Report, establishment of legal services in a law faculty/college is vital for imparting CLE to the students and also to create service-oriented squad of lawyers who would dedicate themselves to the cause of justice. With an aim to provide free legal aid, in the year 1980, under the chairmanship of Justice P.N. Bhagwati (as he then was), the Government of India appointed a 'Committee for Implementing Legal Aid Schemes' (CILAS). This Committee evolved a scheme for monitoring and implementing legal aid programmes all over the country. As there were some deficiencies in the working of the CILAS, therefore, it was felt appropriate to establish statutory legal service authorities at the National, State and District levels so as to provide for the effective monitoring of legal aid programmes. Accordingly, to give effect to article 39A of the Constitution, the Legal Services Authorities Act, 1987 was enacted 'to constitute legal services authorities, to provide free and competent legal services to the weaker sections of the society to ensure that opportunities for securing justice are not denied to any citizen by reason of economic or other disabilities, and to organize Lok Adalats to secure that the operation of the legal system promotes justice on a basis of equal opportunity'. This Act came into force on Nov 09, 1995. As per section 4(k) of the Legal Services Authorities Act, the Central Authority has to 'develop, in consultation with the Bar Council of India, programmes for clinical legal education and promote guidance and supervise the establishment and working of legal services clinics in universities, law colleges and other institutions'.

\section{Phase II}

Subsequent to the recommendations made by the Ahmadi Committee (Committee on Legal Education, with Justice A.H. Ahmadi as its Chairman and Justices B. N. Kirpal and M. Jaganaddha Rao as the other two members) about practical training, the BCI, in the year 1997, issued a circular directing all universities and law colleges to revise the law curriculum to incorporate the following four Practical Papers: (i) Moot Court, Pre-trial Preparations and Participation in Pre-trial Proceedings; (ii) Drafting, Pleading and Conveyancing; (iii) Professional Ethics, Accountancy for Lawyers and Bar Bench Relations; and (iv) Public Interest Lawyering, Legal Aid and Para-legal Services. ${ }^{13}$ However, the BCI prescribed only the number and title of the courses to be offered, and the other details (formulation of the content and number of each paper in the prescribed courses) were left to be evolved by the University Academic Bodies. ${ }^{14}$ This progress marks the second phase in the development of CLE in India. It is also to be noted

\footnotetext{
${ }^{12}$ See Report of the Expert Committee on Legal Aid titled, Processual Justice to the People, Id. at 157. The Report recommended that the law school legal aid clinic would be 'a visible and effective instrument for community education and a wide variety of far-reaching preventive legal services programmes'. It also emphasized upon the importance of CLE as an indispensable component for the professional training of a lawyer.

${ }^{13}$ See the BCI letter LE (Cir.No.4/1997) dated 21 October 1997.

See also, Frank S. Bloch \& M.R.K. Prasad, Institutionalizing a Social Justice Mission for Clinical Legal Education: CrossNational Currents from India and the United States, 13 CliniCal L. Rev. 165, 179-180, 209-212 (2006). http://clarkcunningham. org/LegalEd/Bloch_PrasadArticle.pdf.

${ }^{14}$ See the UGC Curriculum Development Committee Law Report, at 1-2 (2001).
} 
that when the BCI directed the incorporation of the four practical courses, most of the Indian universities and law colleges did not have adequate infrastructure and the required skill to do full justice to the said clinical courses. So, in letter, CLE was made a part of the curriculum, but the spirit was still far away. In the year 2002, in its $184^{\text {th }}$ Report on The Legal Education \& Professional Training and Proposals for Amendments to the Advocates Act, 1961 and the University Grants Commission Act, 1956, the Law Commission of India (LCI), inter alia, made recommendations pertaining to legal education and professional training. The LCI proposed to give prominence to 'legal skills and values' as described in the MacCrate Report, which is the report of the MacCrate Task Force on 'Law Schools and the Profession: Narrowing the Gap' - formed by the Council of the American Bar Association (ABA) Section of Legal Education and Admissions to the Bar. In fact, the four practical courses directed by the BCI, and also stated by the LCI in its 184th Report, revolve around skills akin to those recognized as essential in the MacCrate Report. ${ }^{15}$

\section{Phase III}

The third phase in the development of CLE in India commenced when the BCI framed the Legal Education Rules 2008, which governs the different aspects of imparting legal education in the country. As per the said Legal Education Rules, for regular undergraduate law programmes either in the three-year unitary stream or under the integrated double degree stream (five-year law programme, including the honours programme), students have to study, inter alia, four clinical papers/courses. ${ }^{16}$ The four mandatory clinical courses, as prescribed by the BCI, are:

1. Drafting, Pleading and Conveyance: As the name suggests, this course covers drafting, pleadings and conveyancing. In addition to teaching the relevant provisions of law, this course includes general principles of drafting, practical exercises in drafting, practical exercises in pleadings (civil, criminal, writ petition and PIL petitions) and practical exercises in conveyancing (sale deed, mortgage deed, lease deed, gift deed, power of attorney, Will, etc.).

2. Professional Ethics and Professional Accounting System: This course includes professional ethics, accountancy for lawyers and Bar-Bench relations.

3. Alternate Dispute Resolution: This course includes arbitration law and practice including international arbitration and arbitration rules, negotiation skills to be learnt with simulated programmes and conciliation skills.

4. Moot Court Exercise and Internship: This paper should have three components, that is, (a) moot court (b) observance of trial in two cases (c) interviewing techniques and pre-trial preparations and internship diary.

${ }^{15}$ Bloch \& Prasad, supra note 13 , at 183 .

${ }^{16}$ The Legal Education Rules 2008, in Schedule II, provides the following:

Law subjects (papers) in both the streams

(a) For regular law courses either in the three years' unitary stream or under the integrated double degree stream, students have to take not less than twenty eight papers (subject) in all, which shall include eighteen compulsory papers, four clinical papers and six optional papers from among the list of optional papers under this Schedule and also of any additional papers prescribed by the University from time to time.

(b) For specialized and/or honours course, a student has to take not less than thirty six papers in all, which shall include eighteen compulsory papers, four clinical papers, six optional papers and eight papers in specialized/honours course in any Group ... However if eight papers are taken from multiple of groups, honours can be given in general law without mentioning any specialization. 
Assistance of practising advocates and/or retired judges should be sought for teaching the afore-stated clinical courses. As clinical courses focus on the practical side of the curriculum, therefore, the success of these courses is, in general, directly proportional to the availability of law professors with necessary practical experience. In this context, the practice of involving law practitioners in the classes for clinical courses and/or consulting them in the preparation of course materials to make sure that the content and exercises are realistic - is indubitably commendable, for it does bridge the gap, to a certain extent. However, the ideal situation and the long-term resolution to the issue demand law professors with necessary practical experience handling these courses. The setting and scope of the use of the clinical methodology is strictly restricted in India because of the restriction on law professors and law students from appearing in courts for legal aid. ${ }^{17}$ Thus, one of the important factors that impedes the growth of CLE in India is the embargo on full-time law faculty members from practicing in the court of law. ${ }^{18} \mathrm{~A}$ law teacher with continuous practical experience and exposure would certainly be in a much better position to take up clinical courses and guide the students in these courses more proficiently. Therefore, in order to ensure the complete success of CLE in India, the restriction on full-time law professors from practicing in the court of law should be lifted.

\section{Suggestions for Improving Clinical Legal Education in India}

This part of the article offers a few worthwhile and practicable suggestions pertaining to CLE which may be integrated in the current legal education framework of India so as to make sure the attainment of the higher goal of inclusive justice. These suggestions are as follows:

\section{When and in What Order Clinical Courses Should be Offered}

In general, in India, clinical courses are taught in the third, fourth and fifth years of the law programme. It indeed varies from university to university. One may find these courses being offered in the fourth and/ or fifth years also. In one NLU, three clinical courses are offered in the last semester (tenth semester) of the law programme. ${ }^{19}$ The success of CLE also depends upon how and when these courses are offered. These clinical courses should be treated as instruments for improvising the legal practice and system. It would be much better if the four clinical courses are offered in the second year to the fifth year (one paper in each of these years) of the law programme. It may ideally be started from the fourth semester (second year). There are convincing reasons for offering clinical courses from the second year onwards. First, it becomes really heavy to offer four clinical courses in the last year (or in the fourth and fifth years) because, in such a structure, full justice may not be done to these enormously important courses. Second, students may lack interest in these courses if they are offered towards the end of their law programme, as they would tend to do these courses just for the sake of formality. Lastly, it would be better if from the beginning the potential, aspirations and enthusiasm of law students are tapped appositely, and they start

\footnotetext{
${ }^{17}$ Frank S. Bloch \& Iqbal S. Ishar, Legal Aid, Public Service and Clinical Legal Education: Future Directions from India and the United States, 12 Mich. J. InT'L L. 92, 119 (1990), https://core.ac.uk/download/pdf/232710293.pdf.

${ }_{18}$ Jane E. Schukoske, Legal Education Reform in India: Dialogue Among Indian Law Teachers, 1 Jindal Global L. Rev. 251, 265 (2009).

${ }^{19}$ The National University of Advanced Legal Studies (NUALS). https://www.nuals.ac.in/5-year-SCHEME-OF-COURSES.aspx.
} 
learning and observing the theory and the practical applications of law in these courses from the second year onwards. The author would also like to suggest the following sequence for offering these courses:

1. Professional Ethics and Professional Accounting System: This course may be offered in the fourth semester, that is, second year. The students should learn professional ethics and its importance in the beginning of the law programme. Besides making professionally skilled legal professionals, this course is also to make ethically strong and socially committed legal specialists.

2. Drafting, Pleading and Conveyance: This course may be taught in the third year. Since the aim of this course is to hone the professional skills of students, therefore, offering this course in the fifth year may not serve the desired purpose. The object of this course is to help students understand the importance of legal writing employed by legal professionals, and thus, after having studied some fundamental law courses, students should be oriented to this clinical course.

3. Alternate Dispute Resolution: This course may be taught in the fourth year.

4. Moot Court Exercise and Internship: The components and evaluation methods of this course, as prescribed by the BCI's Legal Education Rules 2008, are such that this course has to be placed in the fifth year, albeit it will take into account the moots done or observance of trials or preparation of internship diary by the students throughout the five years. So, it is in its very nature a continuing course. The final assessment of this course has to be done in the fifth year.

\section{Two Courses on ADR}

Given the increasing importance of ADR mechanisms in resolving disputes, it would be better if 'Arbitration' is taught as a fully taught course (with the main focus on arbitration law, principles and practice, including international arbitration and arbitration rules), and the practical exposure to principles and practice of mediation, conciliation, negotiation, legal aid, para-legal services - is provided to students in the clinical course on ADR. If there is just one course on ADR, then, there is a great possibility that the major focus is given to 'Arbitration', and other mechanisms are not given their due and, as a consequence of which, students are deprived of their learning of the other equally important alternative dispute resolution mechanisms. Hence, the suggestion is to offer two courses: (a) Arbitration Law (as a regular taught course with some practical components) and (b) a full clinical course on ADR (Conciliation and Mediation). Before studying the full clinical course on ADR with the principal focus on mediation and conciliation in the fourth year (as suggested above), students should study the course on Arbitration Law (preferably in the third year). This suggestion would help develop the necessary dispute resolving skills among students; also because it is understood that ADR will be resorted to progressively more in future for resolving disputes, mainly on account of the advantages that it (ADR) offers.

This suggestion is also in tune with a recent letter (dated Aug 13, 2020) sent by the BCI to the Vice Chancellors of all the universities conferring Bachelor of Law degrees. ${ }^{20}$ The said letter "notified that from the academic session 2020-2021, Mediation with Conciliation shall be a course component/compulsory paper/subject for the pursuit of a LLB degree course, both for 3 years and 5 years Integrated courses, (both Honours and non-Honours).' The noble idea underlying this mandate is to provide training in practical skills apart from theory, in recognition of the fact that mediation and conciliation provide amicable, peaceful and mutual settlement between parties without intervention of the court.

${ }^{20}$ BCI:D:1897:2020 (323/2020), 13 August 2020. 
These mechanisms of dispute resolution have the potential to bring forth a great reformation in the Indian legal system, by reducing the burden of courts as also by rendering speedy and effective resolution agreed upon by parties in disputes. As there is no mention of the clinical course on ADR (as prescribed by the Legal Education Rules 2008), one is likely to infer that the BCI is suggesting for an additional course on mediation and conciliation. More so, the said letter of the BCI (first paragraph) provides the scope to the Universities/Centres of Legal Education to incorporate Mediation with Conciliation as a course component/compulsory paper/subject for the pursuit of an LLB degree programme. In consideration of the spirit of BCI's letter and the Legal Education Rules 2008, as stated earlier, the author suggests to offer two courses: (a) 'Arbitration Law' (as a regular taught course with practical components) and (b) a full clinical course on 'ADR (Conciliation and Mediation)'. The specific mention of conciliation and mediation in parenthesis signifies that the clinical course on ADR should principally focus on conciliation and mediation. This suggestion will take care of the spirit behind the BCI's letter and also the Legal Education Rules 2008.

\section{Different Approach for Clinical Courses}

In addition to classroom teaching, clinical courses should include more practical and simulation exercises, preferably with the assistance of practising lawyers and retired judges ${ }^{21}{ }^{21}$ These courses should include activities, such as, field work, socio-legal surveys, legal literacy projects, participation in Lok adalats, developing practical skills required for ADR mechanisms, mock-trial, legal writing, legislative drafting clinics, interviewing and counselling, opinion writing, community lawyering, permitting and facilitating students to work with law enforcement agencies and participation in legal reforms. It would be wise to suggest that universities and colleges should make it a point to hire practising lawyers and retired judges (with academic bent of mind) for teaching clinical courses, along with the specialized law professors. It is incumbent on universities and colleges to conceive clinical courses more comprehensively and creatively, so as to make these courses much more interesting and useful. The approach adopted for other substantive courses in law will not prove to be useful and productive in case of clinical courses. Clinical courses should offer the perceptional, instrumental and operational aspects of the legal profession and the legal system. ${ }^{22}$

\section{Separate Cadre of Clinical Law Professors}

As clinical courses ought to be taught in a different manner, therefore, there is a need for specialized law professors for teaching these courses. Universities and colleges should make serious attempt at grooming and developing specialized law teachers for teaching these courses. Clinical courses should be recognized as specialized courses in the law curriculum. It should even be taken into consideration while recruiting faculty members. Also, the teacher-student ratio should be kept low, particularly for the clinical courses, so that in these courses students work under close supervision of their law professor. Until and unless specialized clinical professors are appointed, the success of CLE in India will remain under serious doubts. Unfortunately, in India, there is no law or regulation prescribing for the appointment of

\footnotetext{
${ }^{21}$ See the Bar Council of India's Legal Education Rules 2008.

${ }^{22}$ Menon, supra note 9 at 4.
} 
specialized law professors (with stipulated qualifications) for clinical courses. By and large, this system is not even initiated in India; one may not even find eloquent research papers or articles on this incalculably significant subject. On the other hand, in jurisdictions, such as, the United States, the culture of clinical faculty is deep rooted. In the US law schools, clinical legal educators are employed in various appointment prototypes (for instance, unitary tenure track, clinical tenure track, long-term contract, short-term contract, and clinic fellowships). ${ }^{23}$

The importance of this suggestion lies in the fact that while (as a short-term goal) assistance of practising lawyers and retired judges (with academic bent of mind) could be taken for teaching clinical courses along with the specialized law professors, but eventually (as a long-term goal), a system has to be developed for creating specialized clinical law professors. In this regard, the following extracts from the Report of the Committee on the Future of the In-House Clinic (published by Association of American Law Schools) is worth mentioning: ${ }^{24}$

'Although the clinical movement began with practitioners used as supervisors, many clinical teachers came to believe that student supervision by practitioners was problematic for a methodology in which teaching was not incidental to the enterprise but rather its primary function. While a practitioner might be a superb lawyer, she would be unlikely to have the training, experience, or time to devote to the teaching role that a full-time clinical teacher would.'

\section{Developing Clinical Jurisprudence and Clinical Teaching Methodology}

First, it has to be understood very well that clinical education is a method of teaching. ${ }^{25}$ There is a need to develop clinical methodology or clinical method of law teaching with the aim of improvising and expanding CLE in India. Legal education with a higher standards of CLE will be socially relevant and professionally remarkable. Clinical methodology or clinical method of law teaching 'assumes a certain degree of commitment to learning on the part of students and a desire for facilitating it in a meaningful way on the part of teachers' ${ }^{26}$ Law students may be permitted to directly assist advocates in representing clients in the courts and tribunals. Clinical methodology or clinical method of law teaching is not developed in India. In the field of CLE, the success India has achieved so far is mainly in terms of incorporating clinical courses in the curriculum, along with some practical exposure in terms of field study, visits, surveys and so on. However, a lot more needs to be done; the emphasis on the clinical courses needs to be transformed and modernized. More number of seminars, conferences and workshops (with CLE as the main theme) should be organized. Such academic events will provide an opportunity to clinical teachers to share their experiences and learn good practices from each other, as also the challenges they face in conducting clinical courses. This will be a pragmatic way for developing clinical jurisprudence and clinical teaching methodology; and this is how the next generation of reforms in legal education and profession can be effectuated.

\footnotetext{
${ }^{23}$ Bryan L. Adamson et al., Clinical Faculty in the Legal Academy: Hiring, Promotion and Retention, 62 J. Legal Educ. 115, 126 (2012). https://jle.aals.org/cgi/viewcontent.cgi?article=1155\&context=home

${ }^{24}$ Dinerstein, supra note 7, at 511.

${ }^{25}$ William P. Quigley, Introduction to Clinical Teaching for the New Clinical law Professor: A View from the First Floor, 28 Akron L. REv. 463 (1995).

${ }^{26}$ Menon, supra note 9 at 12 .
} 


\section{Refresher Courses, FDPs on CLE and Training Programmes for Clinical Teachers}

Refresher courses and faculty development programme on CLE should be organized by the UGC Human Resource Development Centres (previously known as the Academic Staff Colleges) and universities respectively to orient and guide law faculty members for teaching clinical courses and developing clinical pedagogy.

However, the long-term strategy for creating clinical teachers for the future is: introduction of structured and comprehensive training programmes, either in-house or at specialized centres, as unplanned and amorphous approaches may not yield the desired results. In their article, Reflection-in-Action: Lessons Learned from New Clinicians, ${ }^{27}$ Justine A. Dunlap and Peter A. Joy, write that only a small number of law schools have structured in-house training programmes for younger clinical teachers. They advocate that "the same care and consideration that are customarily devoted to developing effective clinical experiences for students should be employed to devise effective in-house training programs for new clinical faculty'. ${ }^{28}$ Besides making recommendations addressing the key concerns challenging new clinical teachers, they have also suggested guidelines for designing and developing in-house training programmes for new clinical teachers. ${ }^{29}$ Accentuating the need of training programmes for clinical teachers, Wallace J. Mlyniec ${ }^{30}$ also writes that owing to various constraints little formal teacher training is in existence at most of the law schools in the United States. These scholarly writings prove that even in foreign countries there is no uniform and standard system for a formal and structured training for creating or grooming clinical law teachers.

\section{Collaborations with Non-governmental Organizations and Government Agencies}

Law universities and colleges should develop collaborations with non-governmental organizations and government agencies with the aim of rendering socio-legal service at the grass root level. This will help develop a much needed social-connect with the society. Furthermore, in addition to experiencing the practical application of law, students will get a sense of contentment that they have helped the needy, not necessarily the poor and underprivileged. The legal aid clinics of law universities and colleges should be expanded further in a meaningful way.

\section{Strengthening Coordination Between Law Universities/Colleges, the Bar and the Bench}

CLE cannot be designed and executed independently of other institutions and legal profession. Rather, a CLE programme works best and is more meaningful when it is integrated into the legal and judicial community in which it operates, and therefore, while implementing a CLE programme, preparation of and

${ }^{27}$ Justine A. Dunlap \& Peter A. Joy, Reflection-in-Action: Lessons Learned from New Clinicians, 11 CliniCAL L. Rev. 49 , 93 (2004). https://scholarship.law.umassd.edu/cgi/viewcontent.cgi?article=1070\&context=fac_pubs

${ }^{28} I d$. at 49.

${ }^{29} \mathrm{Id}$. at $93-99$.

${ }^{30}$ Wallace J. Mlyniec, Where to Begin? Training New Teachers in the Art of Clinical Pedagogy, 18 Clinical L. Rev. 101, 104 (2012)https://scholarship.law.georgetown.edu/cgi/viewcontent.cgi?article=1773\&context=facpub. 
cooperation with all the constituencies is essential. ${ }^{31}$ For accomplishing the real purpose of CLE, law schools, the bar and the bench have to work in coordination.

\section{Providing Adequate Facilities and Resources to Universities and Colleges for Conducting CLE Activities}

CLE requires special funding, without which the tasks and activities of CLE may not be carried out. Therefore, it should be ensured that universities and colleges have adequate facilities and resources for conducting CLE activities. In this regard, the top management and the statutory bodies of the university have to play an important role, for their support has an important bearing on the success of CLE.

\section{Permitting Law Professors to Practice in the Court of Law}

As stated above, the restriction on law faculty members from practicing in the court of law hinders the development of CLE in India. Therefore, it is suggested that law professors should be allowed to practice in the court of law if the state of CLE in India is to actually improve. In order to regulate this aspect, some norms (number of days and/or number of cases in a year and so on) may be laid down.

\section{Augmenting and Expanding the Integration of Clinical Courses in the Curriculum}

Students may be encouraged to engage themselves in CLE (apart from the four mandatory courses stipulated by the BCI) by way of providing them some academic incentives in the form of academic credits. ${ }^{32}$ The BCI mandates four clinical courses; thus, it is open to a university to offer more clinical courses, without compromising other compulsory courses, optional (elective) courses and specialized/honours courses (as directed by the BCI). Another easier way is by incorporating an element of clinical study in

\footnotetext{
${ }^{31}$ Kenneth S. Gallant, Implementing Clinical Legal Education: A Checklist for Programme Design, IN CLINICAL LEGAL EdUCATION 264 (N.R. Madhava Menon ed., 1998). In this chapter, Professor Gallant has raised the questions that would be presented while dealing with all the constituencies (legal and judicial community) in which the CLE programme is to operate. It proposes a checklist of the various legitimate issues to be faced while developing a CLE programme. Answers to these questions are to be found by establishing a CLE programme at a particular university in the context of the national and the local legal system concerned.

32 See Sital Kalantry et al., Promoting Clinical Legal Education in India: A Case Study of the Citizen Participation Clinic (Cornell Law Faculty Publications, Paper 1401, 2012). It is a Joint Report of Cornell Law School (International Human Rights Clinic) and Jindal Global Law School (Good Rural Governance and Citizen Participation Clinic). Some of the suggestions recommended in this Report (at page 40) include the following:
}

1. Amending the relevant rules to allow law professors to practice in the course of teaching a clinical class.

2. Offering students credits for participating in clinics.

3. Law schools should devote resources to hiring clinical faculty and offering clinical courses with low student-teacher ratios.

4. Law professors should develop sustainable clinics.

5. Law schools should partner with NGOs to further the work with communities and advance the social justice mission of education.

6. Funding agencies should fund law school-based legal clinics to engage with communities in strengthening democracy and improving governance for the advancement of justice and the rule of law. 
Asian Journal of Legal Education 9(I)

various other law courses, such as, criminal law, environmental law, labour law, family law, and so on. So as to attach importance to clinical courses, universities may think of allocating more credits to clinical courses. In some way, this might motivate students to pay more attention to these courses.

\section{CLE to be Used for Realizing Constitutional Goals and Values}

Looked at from this perspective, the object of CLE is much greater than merely inculcating the professional skills needed by a lawyer. Rather, from this standpoint, CLE is to be employed for improvising the legal framework, furthering social justice, reinforcing constitutional democracy ${ }^{33}$ and extemporizing public ethos. CLE programme in India should not just focus on instilling what the lawyers do, it rather has to include what legal professionals ought to do. ${ }^{34} \mathrm{CLE}$ is to develop a sense of social commitment in law students that justice is not just for the rich and privileged. Underprivileged and marginalised people are also legally and equally entitled to have access to justice; and that, law students should extend their legal assistance to the poor and needy. This connect of law students to institutions and society (especially the disadvantaged and deprived strata of the society), through various CLE activities, is in itself a goal of CLE, for this connect makes them a better and more sensitive legal professional. More so, this is also a prerequisite to comprehend and enforce, in true sense, Part III (fundamental rights) and Part IV (directive principles of state policy) of the Indian Constitution. Thus, this is one of the effective ways of developing a comprehensive understanding of constitutional values of fairness and inclusive justice in law students.

\section{Raising the Standards for Granting Licence to Universities and Colleges for Running Law Programmes}

The standards of CLE and the manner in which clinical courses are offered should become a nonnegotiable matter for granting licence to universities and colleges for running law programmes. The time has come when the standard of CLE has to be raised. The Inspection and Monitoring Committee of the $\mathrm{BCI}$ that conducts inspection of newly established or existing universities should pay special attention to the standards of CLE. Those institutions which do not have the necessary infrastructural facilities and resources for carrying out CLE should not be granted the licence to run law programmes. Minimum mandatory standards for clinical courses and the manner in which these courses are to be offered should specifically be laid down.

\section{Covid- 19 and its Impact on Legal Education, Particularly on CLE}

It would be a serious lapse if some space is not devoted to the impact of Covid-19 on legal education. The pandemic has wedged every walk of life, let alone education. Owing to the lockdown (March 2020),

\footnotetext{
${ }^{33}$ See Sital Kalantry, Promoting Clinical Legal Education and Democracy in India, 8 NUJS L. Rev. 1 (2015). In this essay, Sital Kalantry argues that CLE promotes democracy, and that there is a pressing need to reinforce CLE programmes in law schools in India for augmenting the democracy and indoctrinating skill-based training to law students, https:/scholarship.law.cornell.edu/cgi/ viewcontent.cgi?article=2619\&context=facpub and http://nujslawreview.org/wp-content/uploads/2016/11/01_sital-kalantry.pdf.

${ }^{34}$ Bloch \& Prasad, supra note 13, at 188.
} 
physical classes had to be suspended nationwide. From the viewpoint of education sector, it is a matter of fact that no one was actually prepared for this global pandemic. Gradually, institutions resumed their academic activities through different online platforms (Cisco Webex, Google Meet, Zoom, Microsoft Jeans and so on), and, one way or another, the January-June 2020 academic semester got over. As the situation was new to everyone, therefore, all the institutions should be appreciated for their efforts in concluding the January-June 2020 semester, notwithstanding some pauses and deferrals. And, when most of the institutions resumed the next academic semester from August 2020, they had to once again resort to the virtual mode only. While it has to be admitted that online classes cannot exactly and substantively replace the actual physical classes, it has also to be acknowledged that there was no other better option than conducting classes via the online mode. From the standpoint of legal education, to a great extent, the online classes prevented the academic loss of students in so far as the regular taught courses are concerned. Nonetheless, the same cannot be said about clinical courses. The pandemic impacted clinical courses the most, owing to the manner in which these courses are expected to be conducted/taught. The author is unaware of any high level deliberation (either of the Vice-Chancellors or Deans of NLUs or other universities) having taken place particularly regarding how to deal with clinical courses, during the pandemic, by way of virtual mode. When the resumption of physical classes was uncertain, ideally speaking, the premier institutes (which the NLUs are in the field of legal education in India) or the Consortium of NLUs should have deliberated upon and come out with some guidelines for universities and colleges imparting legal education in the country for clinical courses. It is humbly suggested that, taking the advantage of the pandemic, the Consortium of NLUs or even individual universities should think of avenues beyond the regular mode for conducting clinical courses, so as to accomplish the real potential of theses courses.

\section{Conclusion}

It is amply clear from the foregoing discussion that in consort with a very strong foundation of substantive law, law students must also be oriented to the practical application of law during their undergraduate law programme through CLE, which intends to conglomerate the theory with practice. An ideal curriculum for the law programme has to strike a balance between these immutable aspects of learning. The advantages of CLE are so much that one cannot afford to give even a slight less treatment to clinical courses. CLE has the potential to promote constitutional values, to uphold the rule of law and to strengthen constitutionalism. Through clinical programmes (legal aid clinics and the like), law students get an opportunity to interact with the poor and marginalized sections of the society. Besides providing legal aids to them, they also get an opportunity to realize the constitutional goals, understand the significance of fundamental rights and resolution underlying the directive principles of state policy. The various activities under the clinical courses should be aimed at achieving these objectives. By converting law students into the agents of social change and champions of justice, CLE serves a wide-ranging purpose. It is, thus, indispensable for the attainment of inclusive justice.

CLE is a pedagogical means by which the all-inclusive learning of law is made possible. Worldwide CLE has reformed the teaching, learning and practice of law. It has emerged as a greatly 'needed bridge between teaching and the practice of the law, as well between academic and society'. ${ }^{35}$ As now it is compulsory to have clinical courses in the law programme, therefore, CLE has become a part of the law

\footnotetext{
${ }^{35}$ Alemanno \& Khadar, supra note 3, at 348.
} 
curriculum in India. Nevertheless, the current state of affairs of CLE in India is not satisfactory, and therefore, the time has come when the reformation has to go beyond the mere incorporation of clinical courses in the curriculum. One of the important reasons for this state of affairs is the lack of any system of appointing specialized clinical law teachers. It is, thus, incumbent on law universities and colleges to bring forth change in the perspective and approach to clinical courses in the law programmes so as to ensure the accomplishment of inclusive justice in India, through the legal education framework. It is the firm belief of the author that by incorporating the suggestions offered in this article, the standards of CLE can indeed be enhanced, and thereby, the overall quality of legal education will also be upgraded. On the subject of professional continuum of legal education and curricular reforms with a focus on practical applications of law, the following concluding remarks made in the Report of the Special Committee on the Professional Education Continuum (Section on Legal Education and Admissions to the Bar, American Bar Association) are worth quoting: ${ }^{36}$

Now more than ever, viewing law school as only part of the professional continuum of legal education is critically important if curricular reform efforts are to bear fruit and if law schools are to continue to be a value proposition for their various constituents. The combination of two comprehensive assessments of legal education, the changing nature of the legal profession, the call for a greater focus on students' practice-readiness, the high cost of legal education and the concomitant debt load that students carry, and other influences make this an especially propitious time to examine carefully what law schools do best and how they can do it better...

Whether or not there is a crisis in legal education, there is undeniably an opportunity for legal educators to look critically at law school curricula and consider the pedagogical choices they have made... Individual faculty members, individual law schools, law school consortia, and other national organizations all have a role to play in seeing this process through to a positive conclusion.

\section{Declaration of Conflicting Interests}

The author declared no potential conflicts of interest with respect to the research, authorship, and/or publication of this article.

\section{Funding}

The author received no financial support for the research, authorship, and/or publication of this article.

\footnotetext{
${ }^{36}$ American Bar Association, Twenty Years After the MacCrate Report: A Review of the Current State of the Legal Education Continuum and the Challenges Facing the Academy, Bar, And Judiciary, 24 (2013), https://www.americanbar.org/content/dam/ aba/administrative/legal_education_and_admissions_to_the_bar/council_reports_and_resolutions/june2013councilmeeting/ 2013_open_session_e_report_prof_educ_continuum_committee.authcheckdam.pdf.
} 